\title{
Fotografia e trabalho escravo: relatos e desafios contemporâneos no Pará
}

\author{
Photography and slave labor: reports and a contemporary challenge in Pará
}

\author{
Geovanni Gomes Cabral* \\ Universidade Federal do Sul e Sudeste do Pará (Unifesspa), Marabá, Pará
}

\begin{abstract}
RESUMO: Este artigo busca tecer uma análise com as fotografias de João Laet, registradas em um resgate de trabalhadores vítimas de trabalho escravo no estado do Pará, especificamente em Rondon do Pará. O objetivo é problematizar as fotografias em seu estatuto documental visual, como elemento potencial de denúncia e resistência ao trabalho escravo. São imagens que retratam formas degradantes de exploração e de violação aos Direitos Humanos. Presente em vários locais do mundo, o trabalho escravo releva a face sombria da violação à dignidade humana, homens sujeitos a trabalhos forçados em diversas frentes de atuação. Vários são os casos de denúncias, investigações, fugas e mortes. Na região norte do país, o estado do Pará apresenta o maior número de ocorrências e de denúncias desse tipo de trabalho forçado, chegando inclusive a ficar acima dos outros estados, conforme dados do Caderno da Comissão Pastoral da Terra (2017). Portanto, as fotografias documentais permitem dialogar com essa memória, com um passado/presente desafiador e ao mesmo tempo urgente, no tocante à justiça trabalhista e aos direitos de homens e mulheres.
\end{abstract}

PALAVRAS-CHAVE: Fotografia. Trabalho escravo. Memória. Conflitos. Comissão Pastoral da Terra.

ABSTRACT: This article seeks to make an analysis with the photographs of João Laet, registered in a rescue workers victims of slave labor in the state of Pará, specifically in Rondon do Pará. The objective is to problematize the photographs in their visual documentary status, as a potential element of complaint and resistance to slave labor. These are images that depict degrading forms of exploitation and violation of human rights. Present in various parts of the world, slave labor reveals the dark face of the violation of human dignity, men subject to forced labor on several fronts of action. There are several cases of complaints, investigations, escapes, and deaths. In the northern region of the country, the state of Para has the highest number of occurrences and complaints of this type of forced labor, even going above the other states, according to data from the Notebook of the Pastoral Land Commission (2017). Therefore, documentary photographs allow us to dialogue with this memory, with a challenging/urgent past/present, about labor justice and the rights of men and women.

KEYWORDS: Photography. Slavery. Memory. Conflicts. Pastoral Land Commission.

\footnotetext{
* Professor da Universidade Federal do Sul e Sudeste do Pará (Unifesspa). Doutor em História pela Universidade Federal de Pernambuco (UFPE). E-mail: geocabral@unifesspa.edu.br.

Orcid: https://orcid.org/0000-0003-0768-8525.
} 


\section{Introdução}

Em quatorze de abril de 2018, recebi o convite do professor Airton Pereira para participar das homenagens que seriam prestadas ao Frei Henri Burin des Roziers (18/2/1930-26/11/2017), no município de Xinguara-PA, distante de Marabá cerca de $245 \mathrm{~km}$. O professor falou que seria um momento importante, principalmente pelo lançamento do livro Apaixonado por Justiça (2018), que contém entrevistas do frei acerca de sua trajetória religiosa e, sobretudo, política. Essa, por sua vez, foi marcada por uma incessante luta pelos direitos humanos, frente aos inúmeros conflitos de camponeses e seus desafios na luta pelo uso e pela ocupação da terra. Para esse momento, também estava reservada uma cerimônia para o depósito das cinzas do Frei Henri, trazidas da França. Essas cinzas ficariam em um memorial construído dentro de um acampamento de trabalhadores rurais sem-terra ligados ao Movimento dos Trabalhadores Rurais Sem-Terra (MST) - que leva o nome do acampamento -, no município de Curionópolis, sudeste do Pará. Tal ação foi realizada para atender sua vontade expressa em uma carta (MOVIMENTO HUMANOS DIREITOS, 2014, s.p.), em que diz "Eu sonho que, quando morrer, eu seja enterrado no meio deles, no 'meu acampamento', e que ao passarem as crianças possam dizer: este é o túmulo daquele frei que lutava conosco pelo nosso direito à terra”.

Havia comentado com Airton, anteriormente, sobre minhas leituras e meus interesse pelas fotografias dos movimentos sociais. Fruto, inclusive, de pesquisas que venho desenvolvendo no acervo fotográfico da Comissão Pastoral da Terra (CPT), na cidade de Marabá-PA. A partir dessa conversa, ele disse que um amigo, o fotógrafo João Laet, iria registrar o evento e que seria uma oportunidade interessante para dialogar sobre seu trabalho e sua experiência. Eu não poderia perder esse momento. No dia seguinte, entre apresentações e apertos de mãos, seguíamos viagem.

A estrada não estava muito boa. Havia vários buracos, devido às fortes chuvas que vinham caindo na região; estávamos em pleno inverno amazônico. Havia, inclusive, trechos da estrada que tinham cedido, devido à força das chuvas. Podia-se ouvir, ao longe, o barulho de máquinas e tratores tentado formar alguma contenção de pedras para os carros passarem. Nesse cenário da viagem, os diálogos foram tecidos. Falávamos da luta pela terra, da violência impetrada por fazendeiros na região, do trabalho escravo e das várias fazendas ao longo do percurso - palco de investigaçôes e conflitos.

João, sempre atento à paisagem, aos movimentos das pessoas na estrada, dos animais que cruzavam o pasto. Seu olhar direcionava-se para a imensidão de cada fazenda, para as áreas de florestas devastadas, para a criação do gado bovino ou para a plantação do milho. Também estavam presentes, nesse cenário, acampamentos, assentamentos, bandeiras do MST ao vento, sinalizando que a luta pela Reforma Agrária ainda resiste. Mulheres, homens e crianças surgiam nos acostamentos, alguns vendendo bananas, outros olhando os carros e caminhóes carregados de soja passarem, mercadorias do agronegócio que se estabelecem e cruzam as terras e fronteiras da Amazônia.

O debate fluía. No almoço, já em Xinguara, foi que o tema da fotografia começou a convergir para minhas inquietaçôes. João Laet, diante de sua simplicidade, contava histórias de alguns registros e dos desafios dessa captura imagética, tão comum em sua trajetória. Lembro que, em uma dessas descriçóes, ele falava que a fotografia tem seu tempo; ela pode ocorrer naquela fração de segundo ou pode até levar dias para acontecer, quando se tratam de projetos fotográficos com certa programação e objetivos mais específicos. Nesse sentido, percebe-se que vários são os fatores que podem corroborar para o olhar fotográfico, na relação estabelecida entre a câmera e o fotógrafo. 
Eu ficava observando atentamente suas câmeras, os ângulos escolhidos, as trocas de lentes em um frenético registro do tempo e da memória. Ele fez toda a cobertura do evento, selecionou imagens, amigos, gestos, movimentos que julgou importantes para a ocasião, silenciosamente, como se a câmera sinalizasse o caminho, a direção da luz. O momento foi singular; lágrimas e afetividades envolvidas. João Laet fez vários registros fotográficos do F rei Henri, em sua passagem pela CPT, e algumas estão inseridas no livro mencionado anteriormente. Na volta para casa, trocamos contatos e João sugeriu que eu acessasse sua página na internet. Aproveitei para fazer algumas perguntas, um breve roteiro buscando entender a sua atuação nesses espaços amazônicos de fronteiras e desafios. Foi quando passei a entender melhor o trabalho e a dinâmica desse profissional. Mas, afinal, quem é esse fotógrafo que percorreu essas fronteiras do sudeste paraense?

João Laet reside, atualmente, no Rio de Janeiro. Vem atuando no ramo da fotografia desde o ano 2000, em vários projetos e atividades. Trabalhou para a CPT, no sul do Pará, entre os anos de 2004 e 2005. Foi fotógrafo do Jornal O Dia, de 2005 a 2016. Recebeu o prêmio Award of Excellence, da Society for News Design, na categoria Photography/Multiple Photos, em 2011, com o projeto fotográfico "Rio em Dois Tempos". Recentemente, trabalhou para Unicef, Adufrj, Instituto Pró Saber, Greenpeace, The Guardian, e em parceria com Agência France-Presse e Foto Arena. Sua página na internet contém fotografias de uma estética única, de um olhar que capta o humano em sua dimensão histórica, cultural e afetiva.

Diante do exposto, este artigo tem o objetivo de dialogar com as fotografias de João Laet, problematizando 29 fotografias que estão em sua página (http://joaolaet.com/) - arquivadas em uma galeria que ele nomeia como "trabalho escravo" - e outras cedidas de seu acervo, que visam a complementar esse eixo investigativo. São 34 registros de homens que conseguiram se libertar da condição de trabalho escravo contemporâneo, em Rondon do Pará-PA, Santana do Araguaia-PA e Xinguara-PA. Como percurso metodológico, utilizo alguns relatos orais do fotógrafo para entender melhor os momentos dos diversos enquadramentos. Essa entrevista norteou toda trajetória investigativa. À medida que eu olhava para as fotografias, descrevia o momento e relacionava-o com a trama da captura da imagem, a tensão, o medo nos olhares se movendo de um lado para outro. Ao ouvir qualquer barulho estranho, eu pensava-se na ação de algum pistoleiro. Escutar o fotógrafo, nesse contexto, é uma ação de aprendizado e de escuta diante da descrição dos registros fotográficos (PORTELLI, 2016). Nada melhor para o historiador do que encontrar esse fio que se conecta na tessitura escriturística. João Laet não apenas descrevia, mas impunha os detalhes dos movimentos executados; suas palavras eram acompanhadas de afetividade, respeito e ética profissional.

Para este artigo, procuro focar apenas nas fotografias do resgate, realizadas em Rondon do Pará, município que pertence à mesorregião do sudeste paraense. A escolha por essas fotografias está relacionada ao fato do fotógrafo ter acompanhado essa ação de resgate, descrita na entrevista, além de seu potencial visual, singularidade e legibilidade histórica. Não pretendo, aqui, discutir a categoria de trabalho escravo contemporâneo, tendo em vista excelentes trabalhos e uma ampla bibliografia que dialogam com essa temática (FIGUEIRA, 2004; GUIMARÃES NETO; GOMES, 2018; BRETON, 2002; SAKAMOTO, 2006), mas possibilitar algumas leituras dessas fotografias como fonte documental, registros de violação aos direitos humanos atrelados às atividades do agronegócio na região. Nesse sentido, faz-se necessário refletir acerca das inúmeras histórias que se materializam nesses enquadramentos; nessas histórias de exploração, violação, degradação, humilhação e escravidão por dívida, e questionar: que leituras e respostas essas imagens têm para 
pensarmos o presente? Que passados estão nesses registros que permitem resistir a tal prática no presente? Para esse debate, divido o texto em dois momentos: o primeiro, $O$ olhar fotográfico, em que busco estabelecer diálogo com historiadores que pesquisam acerca da fotografia e seu estatuto documental, conectando com o trabalho do João Laet, e o segundo, Enquadramento do trabalho escravo, tópico em que procuro analisar dez fotografias escolhidas por sua representatividade e legibilidade diante do resgate dos escravos da carvoaria. Seu tecido imagético surge como uma potência para problematizar essa violação aos direitos humanos. São por esses ângulos de percepção que vou dialogando com as fotografias e com seu autor.

\section{O olhar fotográfico}

Como mencionado, o "olhar fotográfico" de Laet, acerca do trabalho escravo registrado durante o período em que trabalhava como agente da CPT, em Xinguara-PA, despertou não apenas meu interesse, mas leituras diante dessas imagens que congelam olhares, corpos e vidas em movimento. Sua estética visual está presente na construção dessa realidade que, captada pelas lentes de sua câmera, permite caminhar por essa trama fotográfica, por esse instante fragmentado. Boris Kossoy (2014) chama a atenção para esse processo de construção de realidades que, ao mesmo tempo, documenta, tece narrativas e representações visuais. Para o autor, o ato fotográfico está relacionado a três fatores que se conectam diante da captura da imagem: a escolha do tema, o ato do registro e a câmera fotográfica.

A fotografia é o resultado desse encontro. São imagens nítidas criadas pela luz. Ela não surge do acaso, mas parte de uma intencionalidade; o fotógrafo determina o olhar, o direcionamento, a luz necessária para que esse fragmento da realidade possa ser registrado. Ele é o testemunho ocular, o que cria, o que se insere na trama fotográfica. Entram nesse cenário de escolha o tempo decisivo, o momento presente e o exato instante do registro. Percebe-se que a fotografia emerge de uma experiência social e histórica, o que permite refletir sua produção, os campos discursivos, o consumo e a reflexão histórica. A fotografia materializada ocupa um lugar social, um lugar de memória, com valor histórico e documental. Como material da memória, sua imagem é monumento/documento (LE GOFF, 2003, p. 526). Como herança do passado e escolha do historiador, é, respectivamente, experiência e prática. Acerca desse debate, Ana Mauad e Marcos Lopes (2012, p. 274) descrevem:

Assim uma fotografia adquire valor histórico tanto pela sua capacidade de responder às demandas visuais do circuito social (produção, circulação, consumo e agenciamento) organizados por diferentes instâncias da cena pública (imprensa, mercado, estado, movimento social etc.), quanto pelos recursos técnicos e estéticos utilizados para esse trabalho.

$\mathrm{O}$ artigo $A$ fotografia como documento - Robert Capa e o miliciano abatido na Espanba: sugestôes para um estudo histórico, de Ulpiano Bezerra Meneses (2002), possibilita refletir sobre a dimensão histórica que permeia uma fotografia. Nesse caso, ele analisou apenas uma única fotografia de Robert Capa, a do miliciano Federico Borrell García, abatido em plena Guerra Civil espanhola, em setembro de 1936, mostrando que, ao trabalhar com esse tipo de fonte visual, é preciso considerar todos os aspectos atrelados à sua materialidade e produção, ao seu uso e consumo. Ou seja, não é apenas olhar a fotografia, mas pensar em sua trajetória, em suas camadas, práticas 
e circunstâncias históricas, o que Meneses chama de uma biografia da fotografia. Suas ideias corroboram com as pesquisas desenvolvidas por Boris Kossoy no tocante ao tecido fotográfico e suas especificidades.

Nesse mesmo percurso analítico, Alberto del Castillo Troncoso, em seu livro Las mujeres de X'Oyep (2013), realiza uma leitura histórica e investigativa de uma fotografia, tirada em três de janeiro de 1998, no México, por Valtierra. Trata-se do avanço de uma jovem da etnia tzotzil sobre um militar armado com fuzil AR-15. Troncoso faz uma análise de todo o percurso fotográfico, da trajetória e do contexto histórico. Não pretendo, aqui, analisar uma única fotografia, mas seguir alguns apontamentos metodológicos de Ulpiano Meneses, Ana Maria Mauad e Boris Kossoy para a compreensão dessas imagens do João Laet, o que permite pensar nesse recorte de tempo e espaço no sudeste paraense.

Corroborando com os autores anteriormente citados, Boris Kossoy (2014, p. 48) é enfático ao afirmar que “[...] toda fotografia tem atrás de si uma história.”. Ela carrega, em suas impressões, um conjunto de açôes que permitem abordá-la entre diferentes temporalidades, memórias e filtros culturais. Esse tempo interrompido traz, em suas camadas visuais, um passado que se apresenta em diferentes estratos temporais. Não é um passado dado, pronto, acabado, mas indícios, rastros, signos que se apresentam diante do olhar. Ela não é a imagem do real, tal qual, mas uma "[...] representação a partir do real, segundo o olhar e a ideologia de seu autor.”, declara Kossoy (2016, p. 32).

Pensar a fotografia de João Laet é dialogar com esse passado/presente, com suas múltiplas narrativas históricas que vão sendo tecidas com as memórias do ontem, mais as do agora. Nela, encontramos um "olhar engajado" (MAUAD, 2008), no sentido do seu envolvimento social, político e ético diante do trabalho executado junto à CPT (POLETTO; CANUTO, 2002). Não é apenas ir a campo e fazer os registros, mas poder contribuir com essas imagens, denunciando o trabalho escravo, suas dimensões políticas, estéticas e históricas. Nesses termos, “[...] o fotógrafo assume uma postura em face da realidade social que fotografa.” (MAUAD; LOPES, 2012, p. 275). Em seu relato acerca desse engajamento, Laet afirma que "[...] meu posicionamento contra o trabalho escravo se tornou uma bandeira quando essas fotos se revelaram para mim.”" Essa bandeira norteou uma série de outros trabalhos e registros, tendo como foco a luta contra a exploração de trabalhadores e trabalhadoras do campo.

Suas imagens e histórias encontram-se em um tempo pretérito, dialogando com esse presente que se vê instigado diante de seus aspectos visuais. Cabe ressaltar que essa história "recortada" é a "[...] reconstrução sempre problemática e incompleta do que não existe mais." (NORA, 1993, p. 9). Não temos como voltar no tempo, nem mesmo diante de uma fotografia, por maior que seja a lembrança evocada ou rememorada naquele momento. Por meio de suas fotografias, dialogamos com um passado que se encontra enquadrado em seu conjunto de signos, cores, formatos, geometria, silenciamentos e padróes estéticos. É como menciona Ronaldo Entler (2007, p. 30): “Toda fotografia reconstrói seus lugares e personagens com base em códigos estabelecidos por uma tradição. Ser fotografado é, portanto, ser apreendido por categorias estéticas e epistemológicas”. Nesses termos, Giorgio Agamben (2007, p. 29) ressalta que “[...] a imagem fotográfica é sempre mais que uma imagem: é o lugar de um descarte, de um fragmento sublime entre o sensível e o inteligível, entre a cópia e a realidade, entre a lembrança e a esperança.”.

Em seu livro Para entender uma fotografia, John Berger (2017, p. 39, grifos do autor) afirma que "Uma fotografia, ao registrar o que foi visto, sempre e por sua própria natureza se 
refere ao que não é visto. Ela isola, preserva e apresenta um momento tirado de um continuum". Nesses termos, pergunta-se: quais momentos foram isolados nessas fotografias por João Laet em suas atividades como agente da CPT? Em que condições foram registradas e o que elas possibilitam pensar acerca do trabalho escravo contemporâneo? Quais suas especificidades e contextos de produção? Que leituras se podem tecer desse campo visual?

\section{Enquadramento do trabalho escravo}

Neste tópico, busca-se analisar algumas fotografias da operação do resgate de trabalhadores em uma carvoaria, os quais estavam em condições de vulnerabilidade e escravidão no município de Rondon do Pará. As fotografias registradas nessa operação permitem refletir acerca dos dados alarmantes e impactantes, contabilizados no Brasil, em relação ao trabalho escravo contemporâneo (PASSAT, 2017). Os números impressionam, segundo os dados da Organização Internacional do Trabalho (OIT), entre 1995 e 2015, foram libertados, no Brasil, 49.816 trabalhadores em situação análoga à escravidão. Desses, 95\% eram homens entre dezoito e 44 anos de idade, e 33\% eram analfabetos. Dos resgates, a maior parte encontra-se na Amazônia, sendo o estado do Pará o que mais concentra essa atividade ilegal ${ }^{2}$. Diante dessas informações, as fotografias possibilitam perceber que as práticas coercitivas da exploração humana, no tocante às questões trabalhistas, permanecem atuando em diferentes regióes e espaços (sobretudo na região do campo), envolvendo a pecuária bovina e a carvoaria. São grandes propriedades agrícolas em diversas fronteiras amazônicas que convivem com práticas degradantes e exploração de homens e mulheres em ambientes de trabalho forçado. Segundo Ricardo Rezende Figueira (1999, p. 170), estima-se que, entre os anos de 1970 e 1983, houve mais de 83 mil trabalhadores em condiçóes análogas ao trabalho escravo no Brasil. No estudo Trabalho escravo no Brasil do século XXI(2006, p. VI), Leonardo Sakamoto menciona que:

As primeiras denúncias de firmas contemporâneas de escravidão foram feitas em 1971 por dom Pedro Casaldáliga, bispo católico e grande defensor dos direitos humanos na Amazônia. Sete anos depois, a Comissão Pastoral da Terra (CPT) denunciou fazendas, ligadas a multinacionais, no sul do Pará que cometiam esse crime. O depoimento dos peões que conseguiram fugir a pé da propriedade deu visibilidade internacional ao problema. Desde 1985, denúncias de escravidão passaram a ser encaminhadas à Organização Internacional do Trabalho (OIT). Em 1985, o governo federal brasileiro - por intermédio de um pronunciamento do então presidente da República Fernando Henrique Cardoso - assumiu a existência de trabalho escravo perante o país e a OIT. Com isso, tornou-se uma das primeiras naçóes do mundo a reconhecer oficialmente a escravidão contemporânea. 
Imagem 1 - Trabalhadores na carvoaria, antes da chegada dos agentes da Polícia Federal

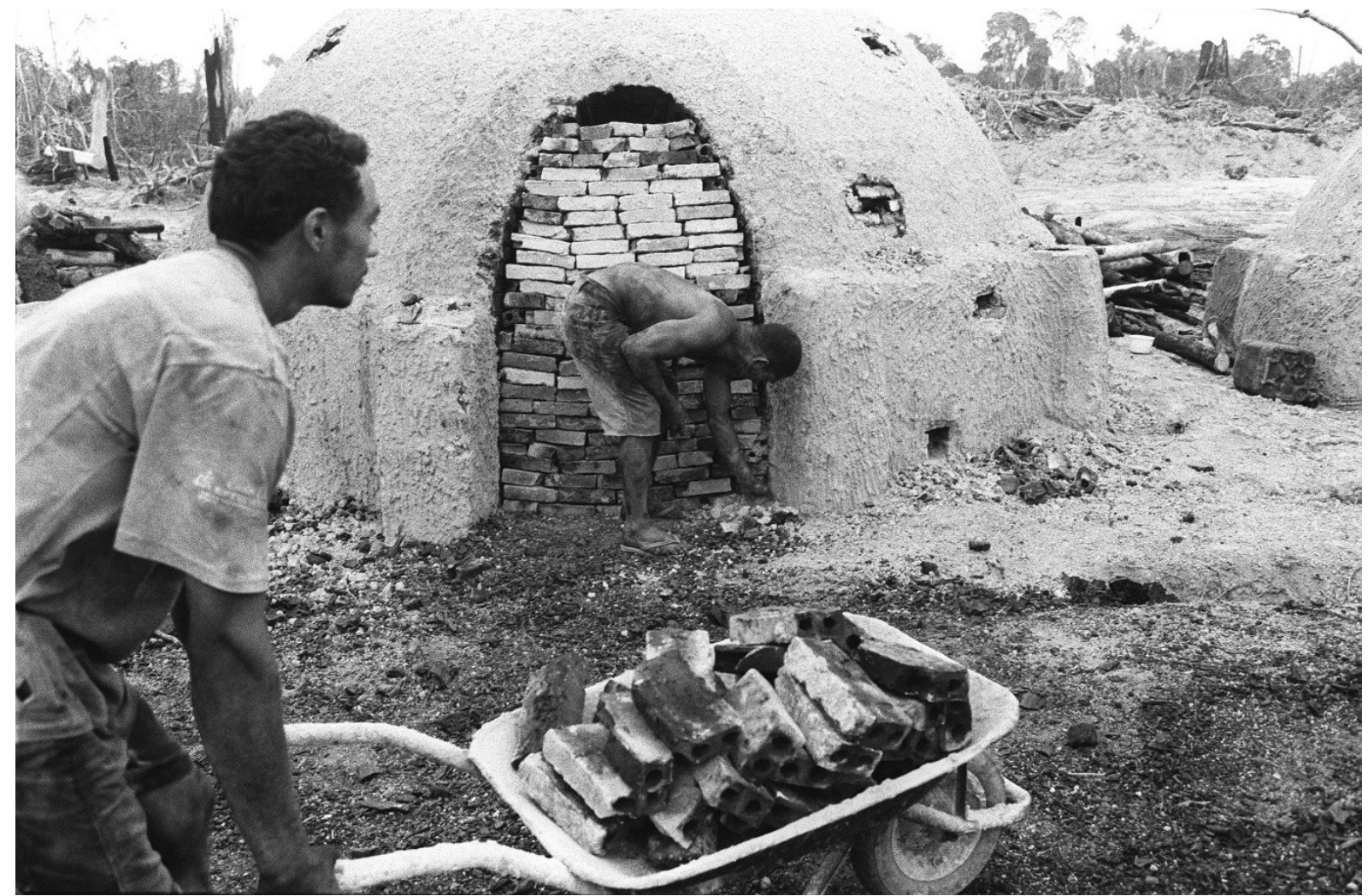

Fonte: Fotografia de João Laet (2005).

Imagem 2 - Carvoeiro finaliza a construção de um forno em Rondon do Pará

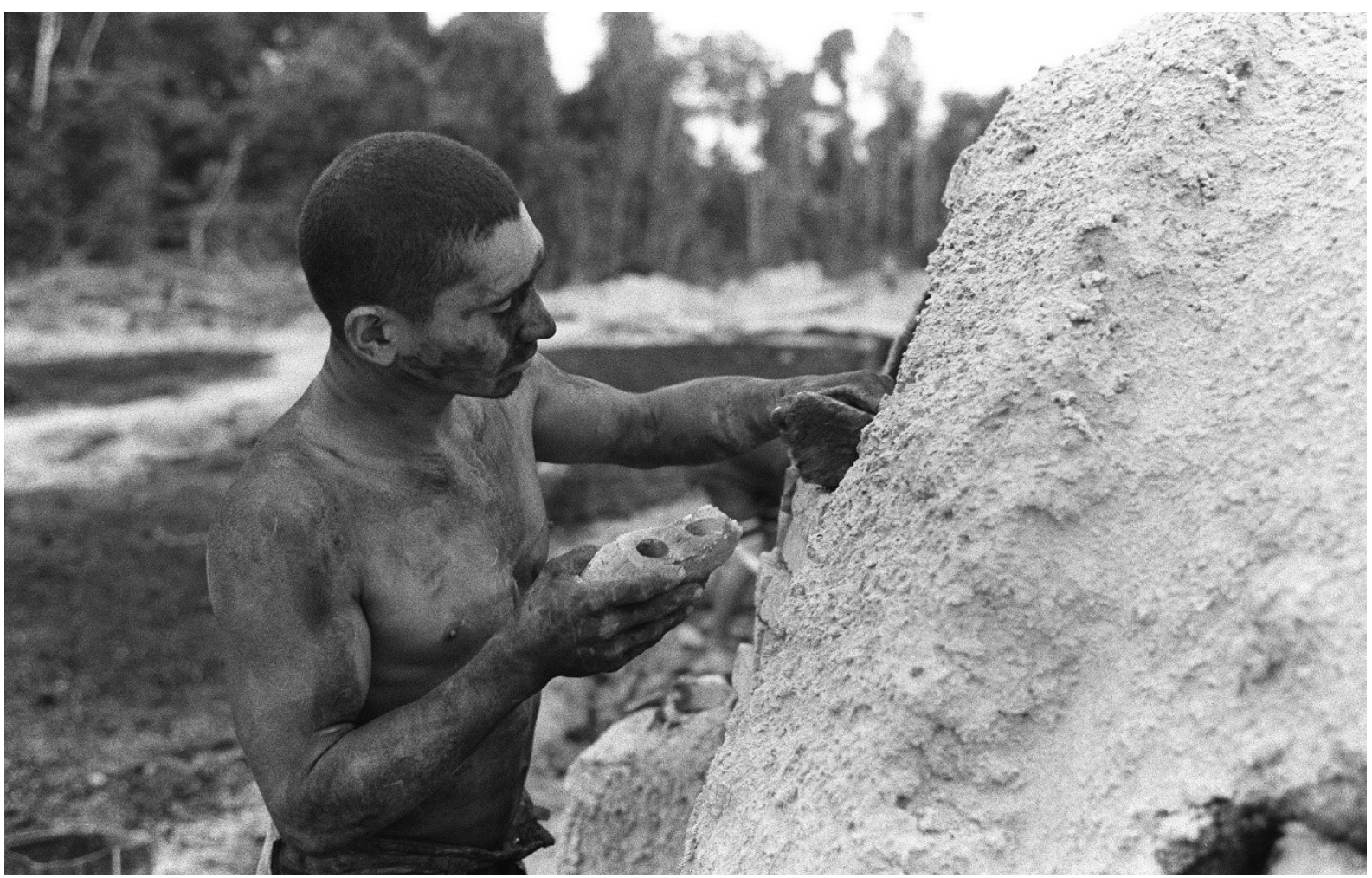

Fonte: Fotografia de João Laet (2005). Realizada durante a inspeção do Grupo Móvel

(Fiscais do Trabalho e Polícia Federal). 
As fotografias 1 e 2 registram momentos da chegada de João Laet à carvoaria em Rondon do Pará. A princípio, foram capturas rápidas de algumas movimentações entre o descer do carro e a visualização da carvoaria. Depois é que surge o diálogo com os trabalhadores para outros enquadramentos. Essas imagens fazem parte da série fotográfica do resgate de trabalhadores, em que esteve envolvido o Grupo Especial de Fiscalização Móvel (GEFM) - composto por Auditores Fiscais do Trabalho, Ministério Público Federal, Procuradores do Trabalho e Polícia Federal. Essa ação consiste em um trabalho de equipe, que tem como objetivo maior garantir a retirada dos trabalhadores da fazenda ou do espaço de vulnerabilidade. Podem-se visualizar, nas imagens, trabalhadores atuando na carvoaria, mesmo sabendo, nesse caso específico, que os órgãos fiscalizadores estavam se aproximando da fazenda. Percebe-se que se trata de um ambiente de trabalho com condiçóes inóspitas, sem a menor estrutura em termos de proteção à saúde do trabalhador. É perceptível que uma parte da floresta foi derrubada para dar lugar à carvoaria e aos fornos. Veem-se cortes de madeira empilhados no chão, troncos de árvores erguidos, ressaltando a destruição da floresta e da vida. A exploração pode ser constatada em vários contextos, desde o humano até o ambiental, como sinalizados nas Imagens 3 e 4 . Nelas, os fornos estão veementes com seus furos expelindo fumaça, jorrando no ar dióxido de enxofre, provocando destruição. À medida que queimam, seus gases são inalados por esses trabalhadores, como algo natural diante das condições em que estão expostos. Até quando isso será permitido no País? As fotografias não apenas mostram um cenário destrutivo e sombrio, mas permitem pensar na fragilidade das políticas públicas de combate a esse tipo de atividade, que se camuflam, que se entrincheiram no meio das florestas, principalmente no sudeste paraense. Espaços não apenas da carbonização da madeira e da produção do carvão, porém local de trabalho forçado, de violação de direitos e da vida. Sobre esse tipo de trabalho na carvoaria, destaca Binka Le Breton (2002, p. 37) em Vidas Roubadas:

A produção de carvão requer muitos tipos de trabalhadores: os que operam as motosserras, os que juntam e empilham a madeira, os que as transportam e os que fazem o carvão. Isto envolve encher o forno - uma tarefa especializada que precisa ser feita com exatidão -, regular o valor esfriar o forno, retirar e empacotar o carvão, A operação completa pode levar até nove dias, conforme o desenho do forno. Famílias inteiras estão envolvidas na produção de carvão e durante o período da queima os fornos precisam ser vigiados 24 horas por dia. Em tais circunstâncias, é difícil até tirar um intervalo de folga, e aqueles que queiram fugir podem se sentir intimidados pela presença de guardas armados. 
Imagem 3 - Carvoarias em plena fornalha

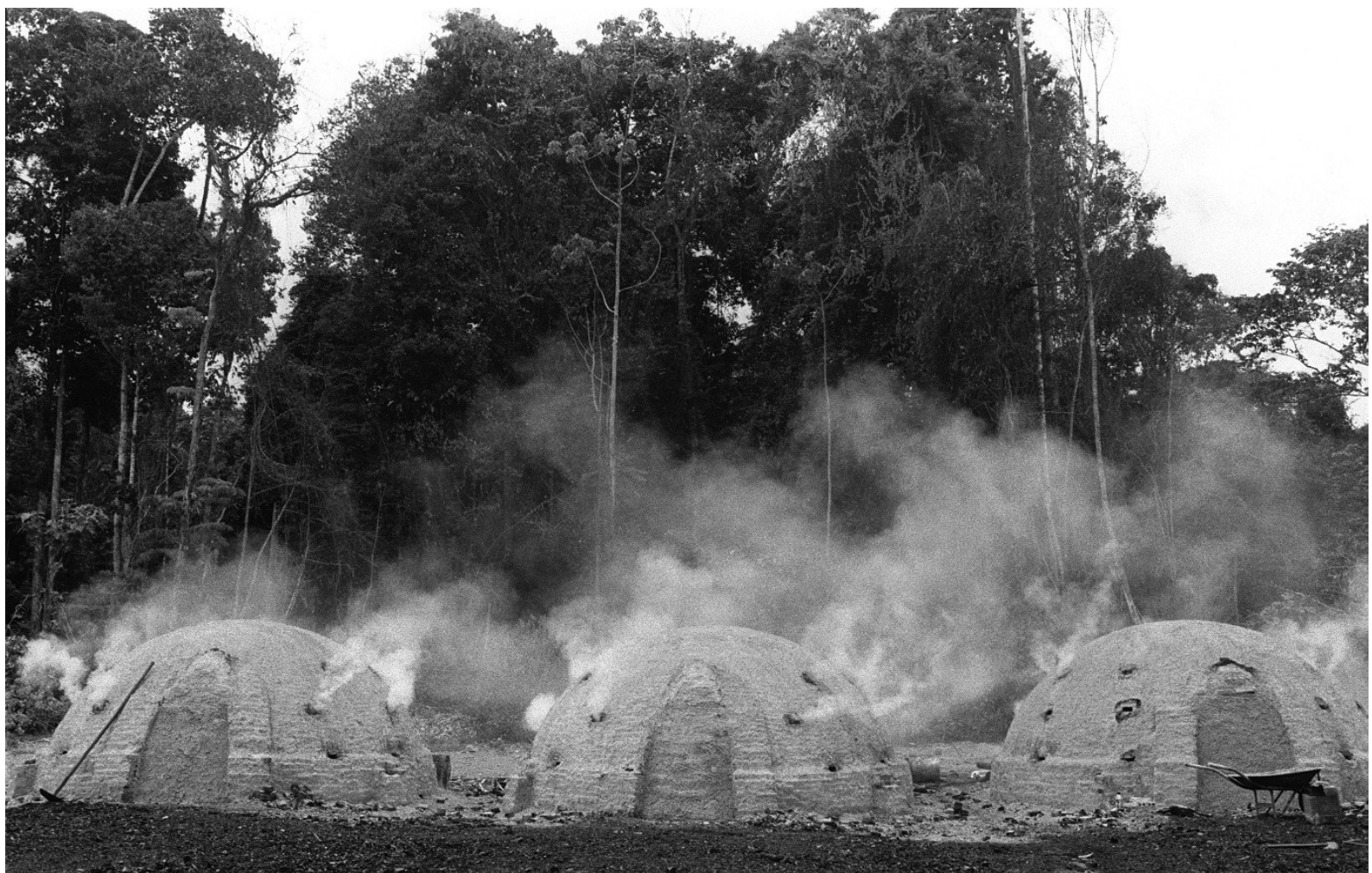

Fonte: Fotografia de João Laet (2005).

Imagem 4 - Vista da carvoaria em funcionamento

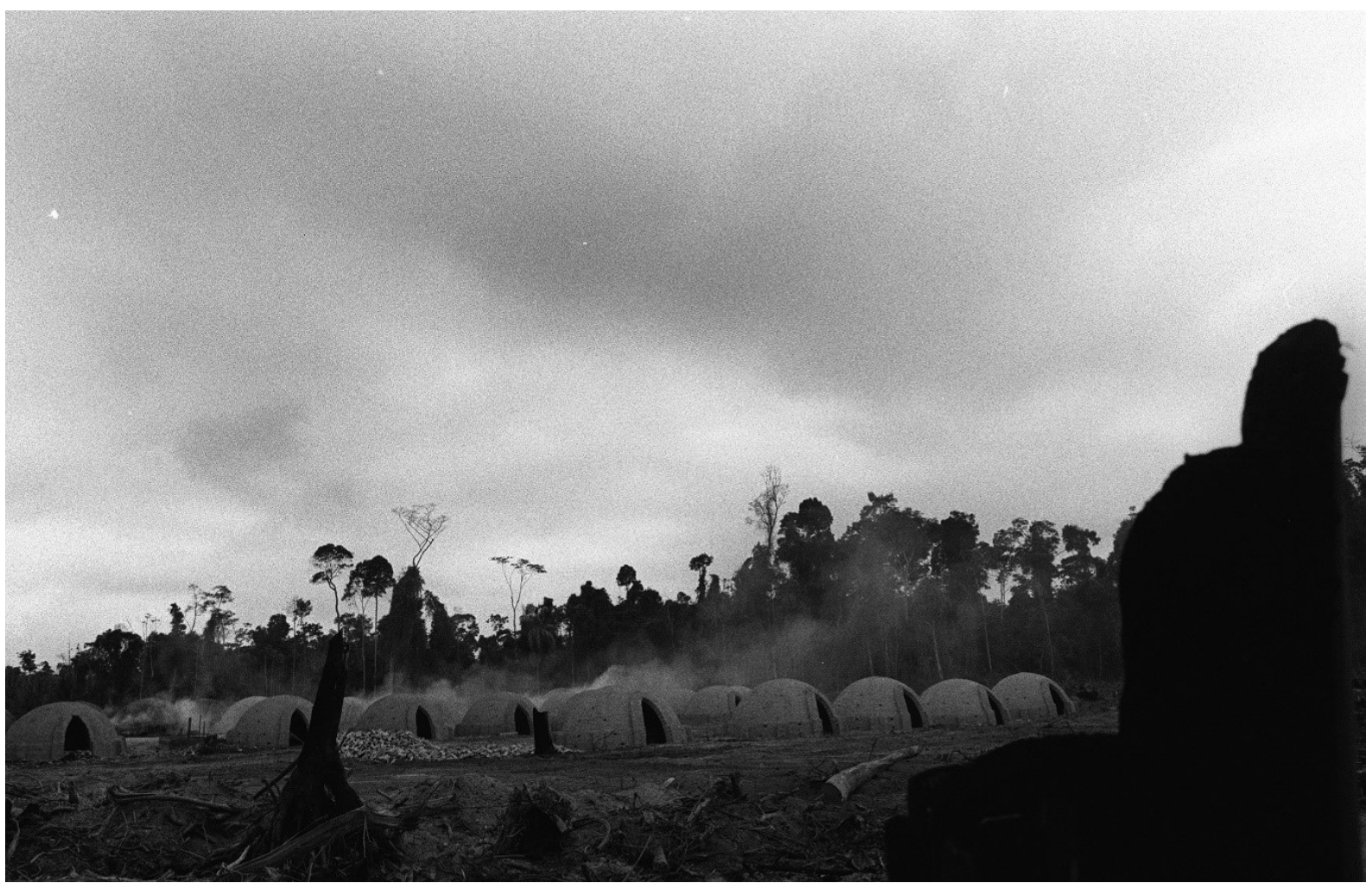

Fonte: Fotografia de João Laet (2005). 
O momento do registro dessas fotografias enquadra-se em um período marcado pelo número excessivo de denúncias de trabalho escravo no sul e sudeste do Pará. Do ano de 2000 em diante, não foi fácil para os representantes do Ministério do Trabalho e Emprego (MTE). Regina Beatriz Guimarães Neto e Airton dos Reis Pereira (2020, p. 135) ressaltam que "Segundo dados da CPT, 54.798 trabalhadores foram resgatados em situação de trabalho escravo entre 1995 e 2018. Mais da metade (27.711) encontra-se nos estados da região amazônica”. E destacam ainda que "Somente no Pará, foram resgatados 13.517 trabalhadores (26,67\%) nesse período (CPT, 2019)". O resgate, do qual estamos aqui apresentando alguns relatos, encontra-se dentro dessa estatística. De acordo com os dados do Observatório da Erradicação do Trabalho Escravo e do Tráfico de Pessoas de 2018, em Rondon do Pará, entre os anos de 2003 e 2018, foram resgatados 433 trabalhadores em situação de trabalho forçado; uma média de 27, 1 resgates por ano ${ }^{3}$.

Nas Imagens 5 e 6, visualizam-se cenas de um alojamento em que os trabalhadores paravam para almoçar ou para dormir. Um fato bem curioso na Imagem 5 , mencionado nos relatos de Laet, é que "[...] tinha um trabalhador de banho tomado, e tudo, que sabia que a Federal já estava chegando, mas ele posou pra mim, para mostrar o alojamento, o local onde ele dormia." “. A imagem é bem contemplativa com potencial para várias leituras. A disposição do trabalhador no centro da fotografia, provavelmente, sob algum banco de madeira, com as redes esticadas, lembra uma cruz. Seu corpo ao centro permite perceber o entorno que quis demonstrar: as condições humilhantes e degradantes do alojamento. Pode-se visualizar um banco de madeira no lado esquerdo da fotografia, dois copos apoiados em uma espécie de mesa, local onde eles realizam as refeições.

Esse "enquadramento planejado" tem um caráter denunciativo e documental, ao mesmo tempo de confiança e atitude política. Laet (2018) afirma: “[...] gosto desse tipo de fotografia documental. É onde me encontro com o próximo e comigo mesmo. Onde me sinto livre para ser quem eu sou e mergulhar no assunto em profundidade." . Esse mergulho está relacionado com o elo estabelecido com os trabalhadores, porque eles se deixaram fotografar "[...] permitiram o registro, de forma espontânea e gratuita. Não sei se os trabalhadores sabiam da importância dessas fotos. Nem eu tinha total consciência. Mas ambos, quiseram que aquele acontecimento ficasse para a história. Mesmo sem saber como se daria” afirma João Laet. Nesse caso, o fotógrafo é o mediador do tecido comunicativo, ele seleciona os detalhes, procura o melhor ângulo, seja no instante do ato fotográfico, seja na melhor pose a ser sinalizada. Sobre os momentos desse registro e sua atuação na CPT, Laet afirma ${ }^{6}$ :

Durante este período estava trabalhando como agente da CPT e a fotografia fazia parte do meu trabalho. É importante dizer que a foto em si é a ponta de um trabalho que começa com um trabalhador, fugitivo de uma situação de escravidão, fazendo a denúncia na CPT. Como ser humano e fotógrafo foi uma experiência única. Eu não tenho foto, claro, dos trabalhadores sendo explorados, mas também não caí de paraquedas quando fotografei estes trabalhadores sendo resgatados e em processo de recebimento dos direitos (tirando a identidade, carteira de trabalho e recebendo pela empreita). Neste momento a CPT também realizava oficinas de combate ao trabalho escravo. Dependendo do número de trabalhadores resgatados pelo Grupo Móvel esta fase final demorava alguns dias e a gente se envolvia ainda mais. As fotos são frutos deste processo. A maior operação de resgate foi na Terra do Meio. Não fotografei a operação, que foi feita junto com o Exército e de helicóptero. Os trabalhadores resgatados nesta operação fotografei em Marabá. As demais operações foram em Santana do Araguaia e Rondon do Pará. 
O relato do fotógrafo possibilita-nos problematizar os desafios do registro, principalmente por envolver vários órgãos de combate ao trabalho escravo. Interessante perceber que, por meio de uma denúncia, conseguiram chegar a esses trabalhadores e que nem sempre os registros fotográficos são possíveis nessas operações. As fotografias desse momento pós-resgate trazem, em seu campo visual, o alívio diante da situação, mas também o medo dessa nova fase. Uma vez libertos, poderiam encontrar sua família, tirar os documentos e trabalhar de forma digna, sem violar os direitos trabalhistas, muito menos os direitos humanos. Interessante que o fotógrafo se vê inserido nessas questôes, passa a vivenciar esse contato humano, esses “olhares da escravidão” que chegam até ele. Não há como não se sensibilizar diante dessas ações. Percebe-se que, para essas fotografias, além da produção do Laet, existiu toda uma confiança no trabalho executado, que é outro elemento que se faz presente nessas negociações. Não é chegar e fotografar e postar na página. O respeito pelo próximo é algo fundamental nesse tipo de atividade fotográfica. Prevalece o diálogo e a confiança diante do ato fotográfico.

\section{Imagem 5 - Trabalhador mostrando seu alojamento}

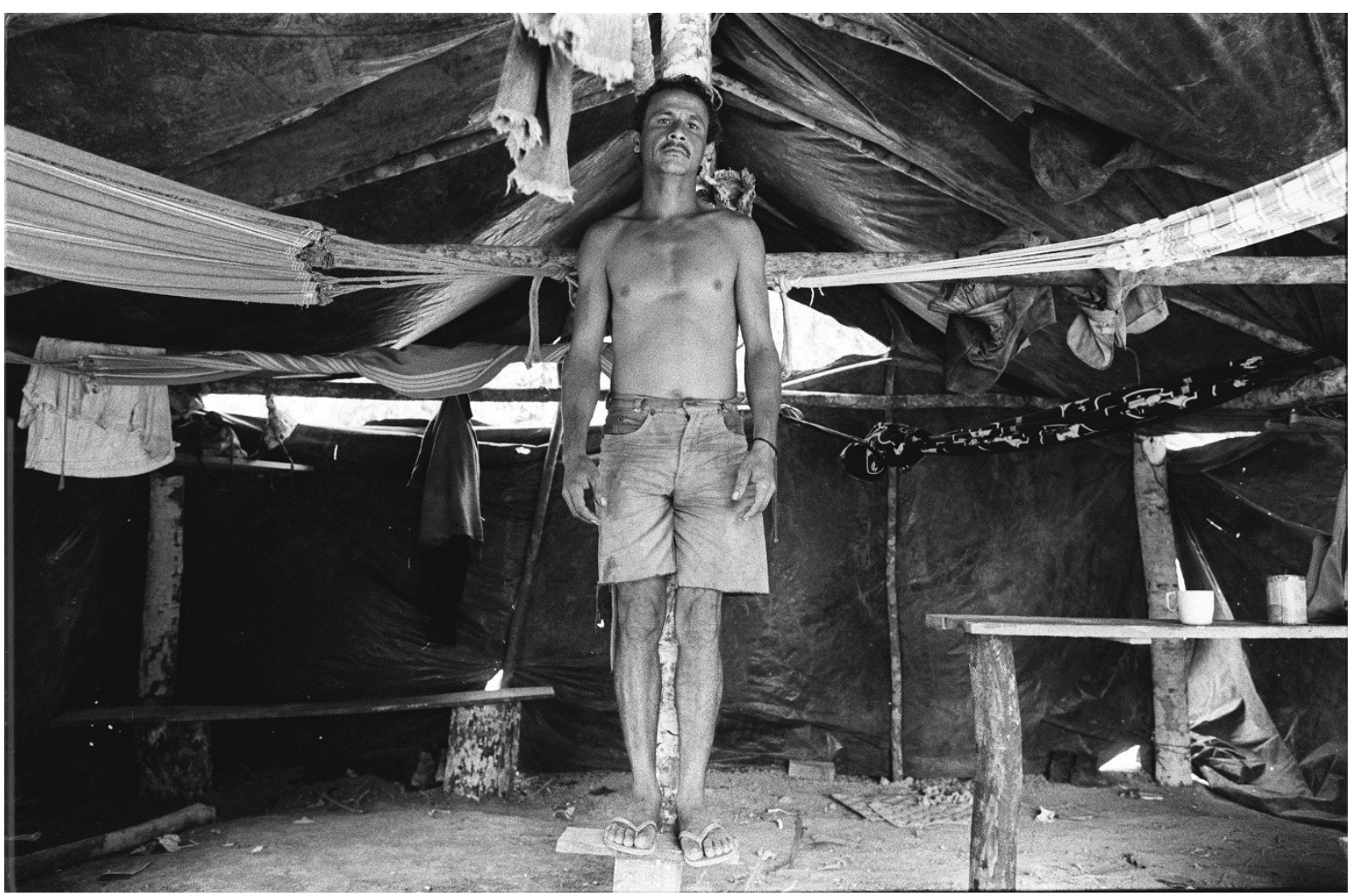

Fonte: Fotografia de João Laet (2005). 


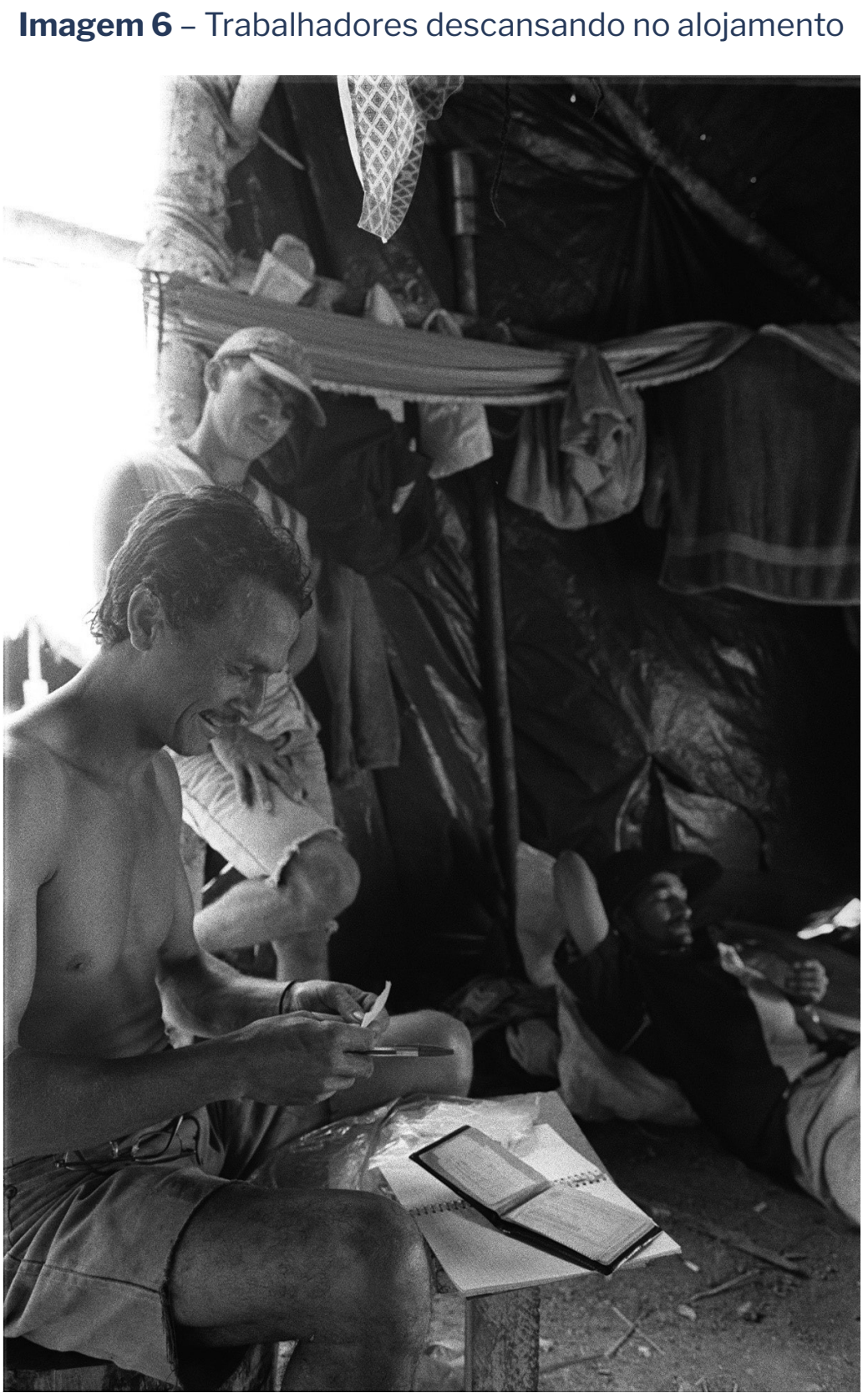

Fonte: Fotografia de João Laet (2005).

É importante pontuar que as fotografias estão todas em preto e branco. Para a escolha dessa tonalidade, o fotógrafo menciona que "[...] é muito rico em termos de tons e de detalhes na imagem.”. Fala, por exemplo, de algumas referências dentro do universo fotográfico que o inspiraram ao logo da trajetória, no tocante às cores preto e branco, como "[...] as fotografias do João Ripper, sempre foram referências para mim. Assim como as fotografias da Agência Magnum, fundada em 1947, por Robert Capa, David Seymour, Henri Cartier-Bresson, George Rodger e William Vandivert; das fotografias da Segunda Guerra Mundial e da Guerra Civil Espanhola.”. Tal argumentação fez-nos lembrar do pensamento do fotógrafo norte-americano Robert Frank (LOWE, 2017, p. 186), que afirma "Preto e branco são as cores da fotografia. Para mim, elas simbolizam as alternativas da esperança e do desespero às quais a humanidade está sempre sujeita.”. A inspiração de João Laet, pela dicotomia fotográfica, não é mostrar a ausência de outras cores. Ao contrário, é poder 
sinalizar o potencial entre a luz e a sombra, que emerge desses registros que têm seu olhar como testemunho, que apresentam a imagem no lugar da palavra, com seus detalhes e especificidades.

As fotografias de João Laet representam esse "humano" silenciado por um ambiente de exploração, degradante e de extrema vulnerabilidade. Ele busca, nas feições humanas e no momento do enquadramento, o natural, o belo, a denúncia, o desejo e a dor (SONTAG, 2013) que, mesmo congelada no tempo, ultrapassa as retinas. Quando eu me deparo com suas fotografias, vejo o olhar da angústia, do desespero, da revolta diante da violação aos direitos humanos. Seus registros, mesmo trazendo um tempo passado, dialogam com um presente de revoltas, fugas e denúncias envolvendo trabalhadores escravos em todo o Brasil. Visualizam-se, na fotografia a seguir, três trabalhadores de olhares concentrados - principalmente o que se encontra no primeiro plano da foto, cujo olhar pode sinalizar medo e desconfiança diante da operação do resgate (Imagem 7). A imagem passa uma ideia de que alguém está explicando algo, e eles estão atentos escutando. De fato, chega um determinado momento do resgate em que os trabalhadores são ouvidos e recebem explicações sobre quais são seus direitos trabalhistas, como proceder para assinar a carteira de trabalho, receber o seguro desemprego e indenizaçóes pelos anos de exploração. Também recebem informaçóes sobre como se prevenir para não cair nas promessas enganosas de gatos e proprietários de carvoarias e de fazendas da região, e como procurar apoio junto aos Sindicatos dos Trabalhadores Rurais (STRs) e às instituiçốes como Comissão Pastoral da Terra (CPT) e ao Ministério Público do Trabalho (MPT). É uma atividade de várias etapas, nem sempre de fácil solução, principalmente por envolver latifundiários, serviços de pistolagem e ações jurídicas. 


\section{Imagem 7 - Trabalhadores observando a atuação do Grupo Móvel}

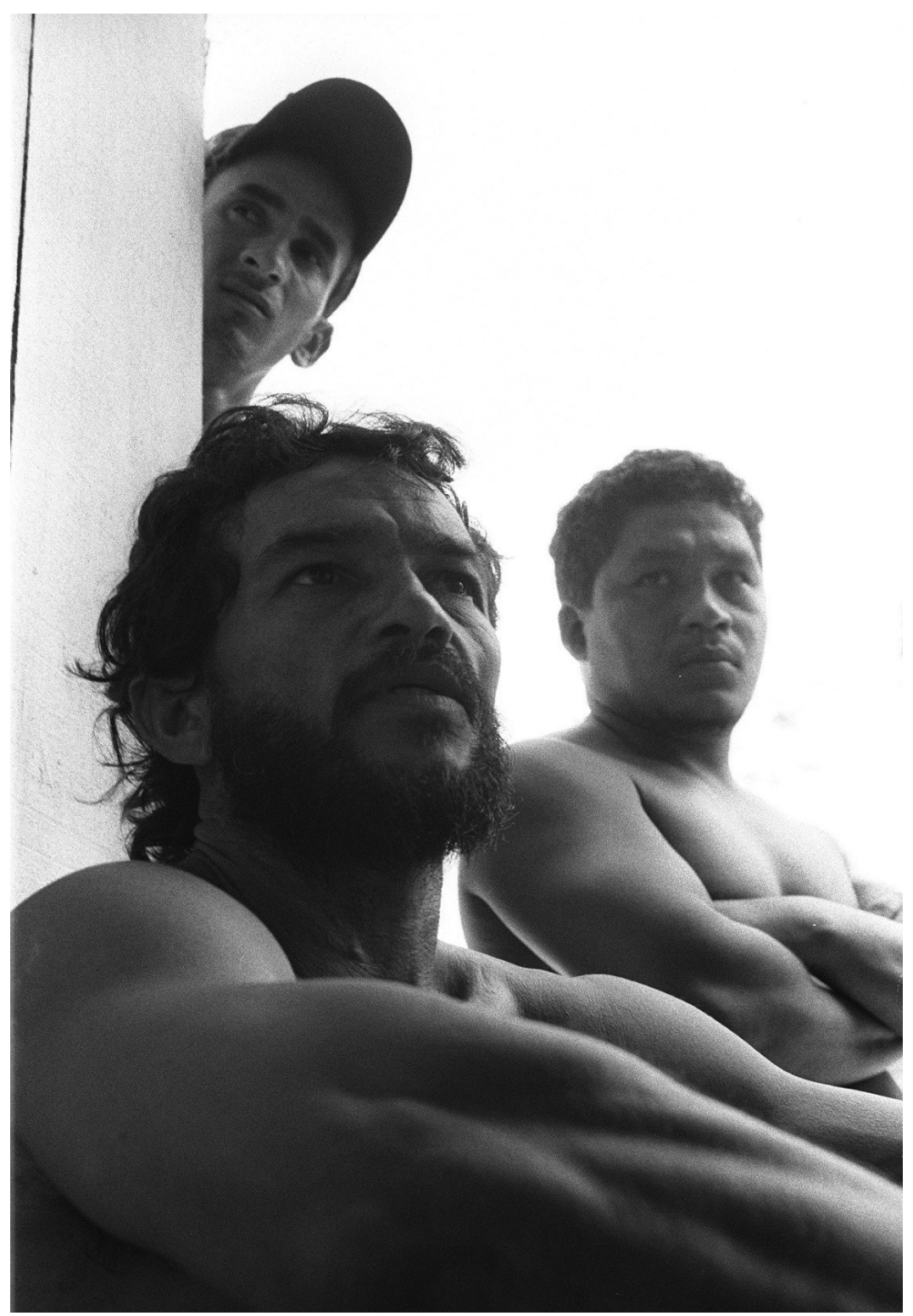

Fonte: Fotografia de João Laet (2005).

Esses homens que chegam nesses locais para trabalhar são levados por aliciadores, empreiteiros ou "gatos", como são conhecidos na região. Eles têm a função de "contratar" mão-de-obra para executar as atividades da fazenda. Fazem promessas, deixam dinheiro com a família, criam um cenário cheio de ilusões e fantasias. Seguram suas carteiras de trabalho na eminência de poder registrar - coisa que não acontece - e essas não são devolvidas. Chegando ao local, passam a trabalhar em condições degradantes, com jornadas de trabalho excessivas, isolados de outras pessoas e, muitas vezes, até prisioneiros em fazendas e carvoarias. Isso sem mencionar os maus tratos e a violência, inclusive em executar o trabalho sob a mira de armas de pistoleiros (FIGUEIRA; PRADO, 2011; SILVA, 2008). Mas quem são esses trabalhadores que são aliciados e postos nessas condições de trabalho escravo? Diante dos dados do Observatório da Erradicação do Trabalho Escravo e do Tráfico de Pessoas, de 2003 a 2018, referentes ao município de Rondon do Pará, e tomando como exemplo os que residem na região, percebe-se que $60 \%$ trabalham na agropecuária e $17 \%$ 
na carvoaria, 39\% têm escolaridade até o 5o ano e 33\% são analfabetos. Desses, apenas 14\% têm o ensino fundamental incompleto e $5 \%$ completo. No tocante à faixa etária, prevalecem homens de dezoito a 59 anos de idade, sendo que o grupo com maior registro desse tipo de exploração ocorre entre dezoito e 24 anos de idade. Essas informações permitem entender esse fluxo de migrações, aliciamentos e vulnerabilidades. São homens que estão em busca de melhores condições de vida para si e para o sustento da família. Muitos se veem diante de propostas tentadoras e, de repente, sem perceber a trama da negociação, estão executando trabalhos forçados cercados de pistoleiros. As fotografias de João Laet chamam a atenção para esses dados. Seu registro foi possível mediante uma fuga e uma denúncia. Caso contrário, o silenciamento e o medo teriam permanecido. Para Maria Antonieta Vieira (2008, p. 232):

São trabalhadores migrantes sem-terra, que vivem em bairros rurais ou nas periferias das cidades, mas trabalham basicamente no campo. Alguns possuem pequenas áreas de terra ou cultivam lavouras de subsistências em sistema de arrendamento ou parceria. Possuem pouca ou nenhuma qualificação profissional e baixa escolaridade. Esses trabalhadores podem ser divididos em três grupos: os que vivem na região e se deslocam para municípios vizinhos ou dentro do mesmo estado à procura de trabalho temporário; os que atravessam grandes distâncias, deslocando-se de outros estados e retornando para casa depois de meses de trabalho temporário; e os chamados 'peões de trechos', que não retornam para casa, a não ser eventualmente, e que fazem do deslocamento permanente seu modo de vida.

Em uma das fotografias desse resgate, o trabalhador fez questão de exibir para o fotógrafo a "página" da caderneta de contabilidade da carvoaria, em que eram registradas as compras dos produtos na cantina da fazenda. Ou seja, eles chegavam ao local de trabalho sem dinheiro, apenas com a "força de trabalho" e tudo que consumiam era anotado nesse caderno. No final do mês, ao receber o dito "salário", o trabalhador pagava o que devia e voltava a comprar tudo de novo. Isso quando recebia alguma coisa. Caso contrário, aumentava a dívida, não conseguia pagar o alimento e voltava para o trabalho. Nessa prática abusiva, eles não tinham como visitar sua família, estavam presos a uma situação criminosa, não conseguiam quitar a dívida gerada pelo empregador, como forma de os manterem presos no local de trabalho (SILVA, 2008; CAVALCANTI, 2020).

$\mathrm{Na}$ caderneta, podemos visualizar as anotações de $2 \mathrm{~kg}$ de feijão, uma manteiga, $10 \mathrm{~kg}$ de arroz, um pacote de café, um óleo, produto de limpeza, cartela de ovos, farinha, bem como produtos de higiene pessoal, um barbeador, um creme dental e um sabonete. Itens que integram a cesta básica, o que eles chamavam de "boia” (Imagem 8). Na imagem 8, podem-se ler alguns nomes de trabalhadores, como Paulo, Raimundo, Adão, Edson e Gilson. As compras eram registradas e controladas, vários itens se misturavam no "kit" de sobrevivência. Para cada trabalhador, era reservada uma folha para anotação, como esta, por exemplo, do "Gesus fazedor de fornos", nome que aparece na parte superior da fotografia (Imagem 9). Tecendo algumas leituras dessas fotografias, percebe-se seu potencial imagético acerca das práticas de endividamento e dependência desses trabalhadores (SILVA, 2008), que se viam diante de um controle por parte dos fazendeiros e de seus encarregados. O foco dado pelo fotógrafo ajuda a perceber as relações de poder que eram estabelecidas nessa carvoaria, antes da chegada do Grupo Móvel para resgatá-los. As imagens das cadernetas não só reforçam o endividamento, como possibilitam refletir sobre a restrição de locomoção desses trabalhadores, que se viam presos a uma situação de controle da vida e da liberdade. A pedido do fotógrafo, o trabalhador exibe, com suas mãos, a caderneta, os registros e os nomes 
das mercadorias consumidas, o que reforça o indício da prática escravista forçada. Sua importância se dá, justamente, nesses detalhes, nesses indícios investigativos que a imagem consegue destacar. Olhar para esse conjunto de fotografias não é somente visualizar um tempo passado. Apesar de essas imagens retratarem dor, violação e escravidão, em uma fazenda no município de Rondon do Pará, é possível pensar no presente e nos números gritantes desse tipo de atividade, que se mantém com força no Brasil, principalmente no estado do Pará. As imagens de Laet apresentam-se como uma forma de não silenciamento, de denúncia, engajamento e resistência. Seus enquadramentos mostram um Brasil desigual, um Brasil que ainda escraviza, destrói suas florestas, é desumano, e que deixa esvaziar os direitos de trabalhadores e trabalhadoras em nome de um progresso vazio diante dos olhos da Constituição do País e do Código Penal (artigo 149).

Imagem 8 - Detalhe da página do caderno de contabilidade

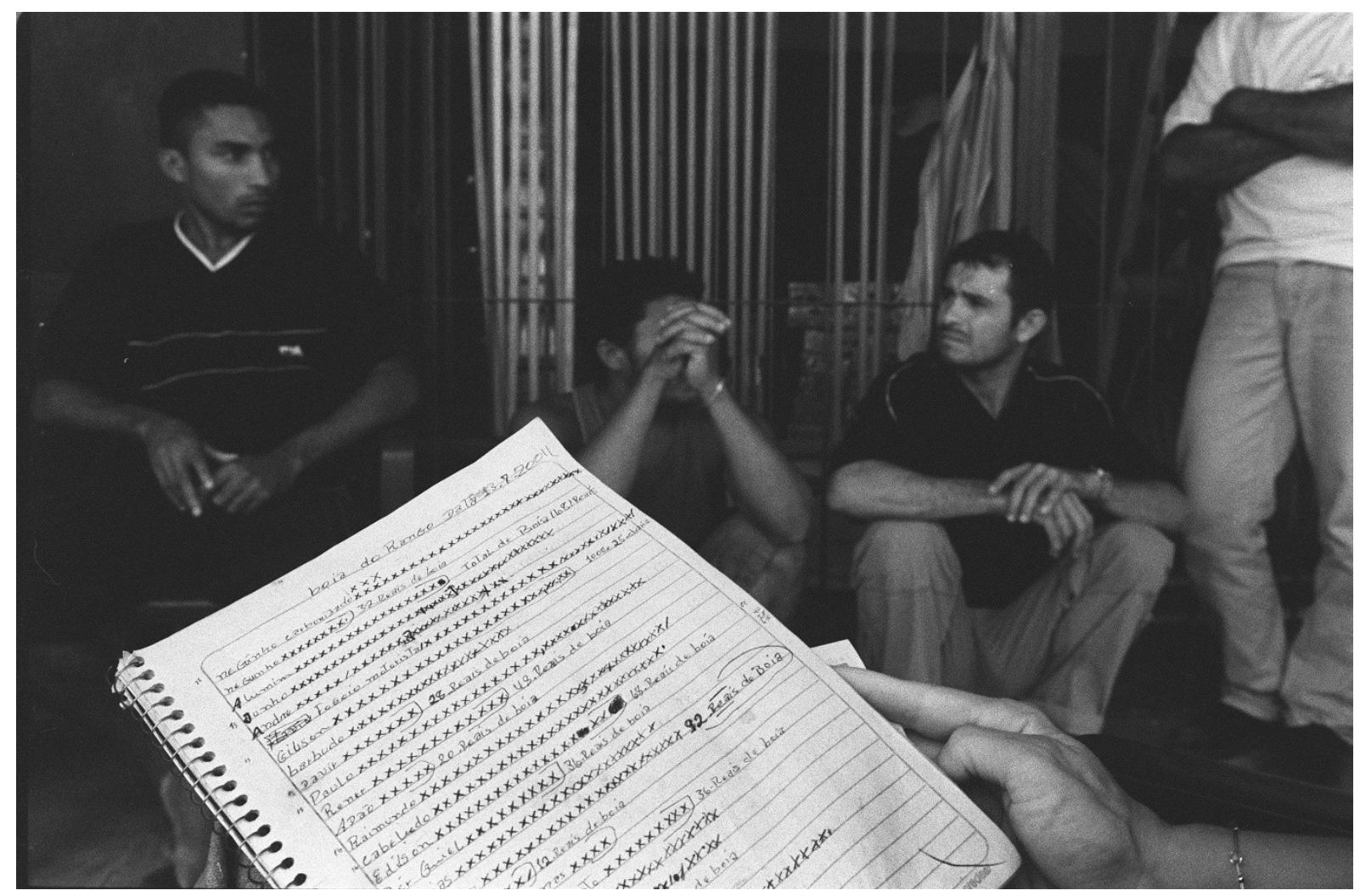

Fonte: Fotografia de João Laet (2005). 
Imagem 9 - Trabalhador exibindo a caderneta de contabilidade

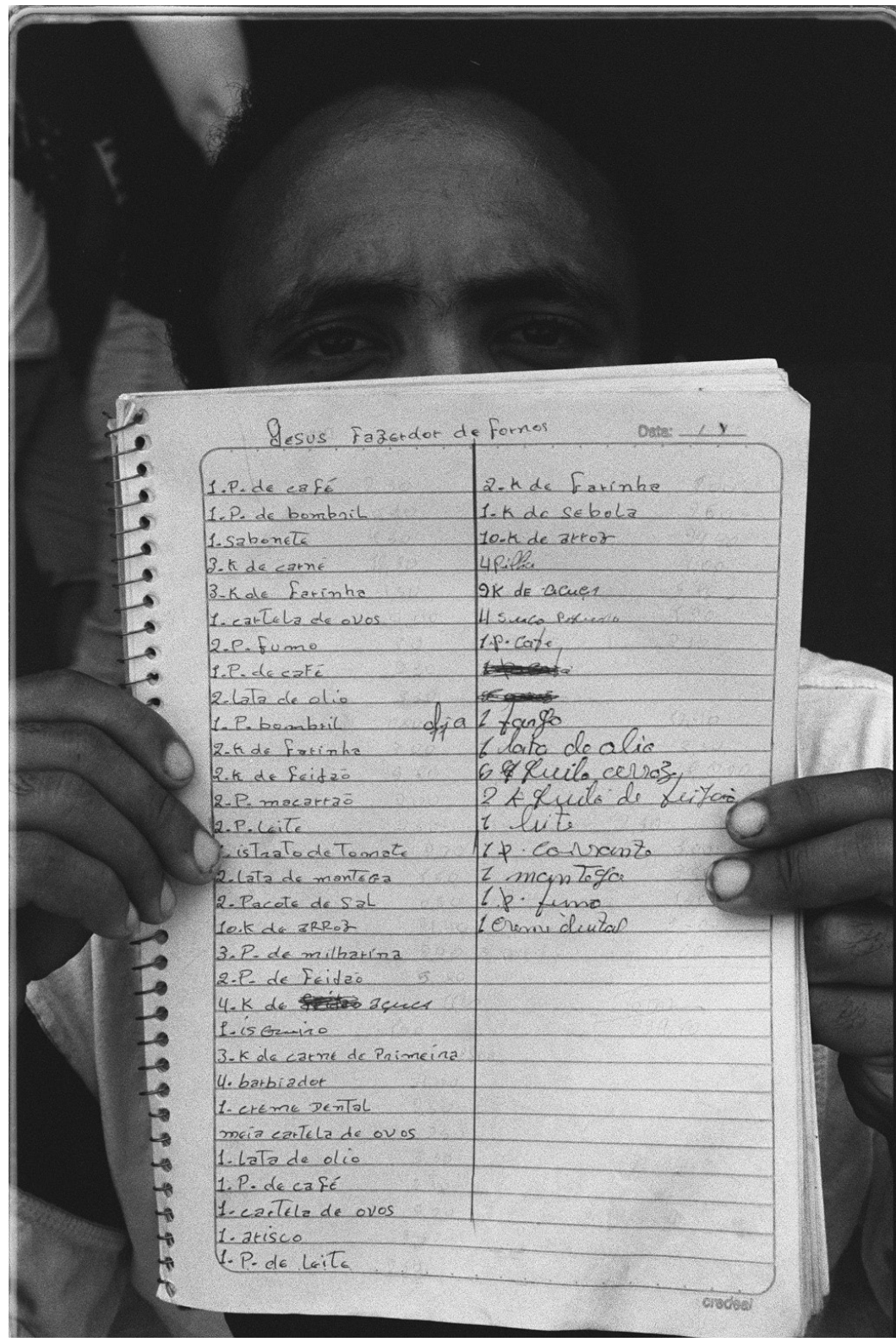

Fonte: Fotografia de João Laet (2005).

\section{Considerações finais}

Vou começar essas considerações com um trecho da Judith Butler (2018), de seu livro Quadros de Guerra: quando a vida é passivel de luto?. Nele, a autora menciona que "A fotografia, exibida e colocada em circulação, torna-se a condição pública mediante a qual nos indignamos e construímos nossas visões políticas para incorporar e articular a indignação”. Seguindo esse pensamento, não há como não se indignar com as fotografias do resgate em Rondon do Pará. Não com sua estética visual, mas com as representações do trabalho escravo contemporâneo, que estão escondidas em fazendas e grandes propriedades. 
As fotografias de João Laet caminham na linha investigativa/documental, propóem discussões, revelam homens, corpos e rostos em condiçóes degradantes de trabalho escravo em uma carvoaria. Essas fotografias dialogam com o trabalho realizado por João Ripper e Sérgio Carvalho (2011) no livro Trabalho escravo. Uma série de imagens capturadas em diferentes temporalidades, espaços e fronteiras do Mato Grosso do Sul, Pará, Piauí e Maranhão, de São Paulo e da Bahia. Ambos os trabalhos apresentam um Brasil que ainda convive com práticas de "escravidão contemporânea” que violam a vida, a dignidade e os direitos humano.

Ao visualizá-las, não se sente o cheiro da fumaça, nem o barulho do corte das árvores pelas motosserras, que as fortes imagens revelam, muito menos a sensação de liberdade enfrentada por esses trabalhadores com a chegada do Grupo Móvel e seus agentes federais. Mas podemos utilizá-las em sua materialidade e visualidade como um veículo de combate e resistência, com suas múltiplas leituras, signos e enfrentamentos. São homens que inclinaram seus olhares, corpos e vidas para serem "enquadrados” em cenários de destruição e morte.

Portanto, trazer e problematizar as fotografias de João Laet permite refletir sobre a dimensão documental e seu uso no campo da história. Seu potencial reside no registro propriamente dito, na trama estabelecida e nas intenções de produção. Para cada imagem capturada, encontra-se uma narrativa, uma história, um registro capaz de falar em diferentes camadas de tempo. Ela não fala por si, precisa das conexôes (outras fontes) e suas respectivas temporalidades. Possibilita pensar neste Brasil desigual, em uma escravidão que se faz presente nas fazendas e nos espaços clandestinos, na destruição da floresta, na emissão de gases poluentes frutos da queima da madeira para a fabricação do carvão vegetal. As fotografias dialogam com os dados da Organização Internacional do Trabalho e com as informações do Observatório da Erradicação do Trabalho Escravo e do Tráfico de Pessoas, no tocante aos números expressivos de resgates e inspeções, principalmente nos municípios de São Félix do Xingu, Marabá e Rondon do Pará.

Olhar para as fotografias de João Laet é pensar no estatuto documental visual que elas representam acerca da escravidão contemporânea no sudeste paraense. Um registro que, apesar das múltiplas leituras que são tecidas em volta de seu campo imagético, funciona como um fator de resistência, de denúncia, de não silenciamento, um ato também político e ético. Visualizá-las, ler suas camadas de tempo, perceber seu jogo de luz e sombra permite lembrar e não esquecer que o trabalho escravo está atuante e firme em suas diversas práticas exploratórias, principalmente no sudeste paraense, foco de toda discussão.

\section{Referências}

AGAMBEN, Giorgio. Profanações. Tradução de Selvino José Assmann. São Paulo: Boitempo, 2007.

BERGER, John. Para entender uma fotografia. Organização e introdução de Geoff Dyer. Tradução de Paulo Geiger. 1. ed. São Paulo: Companhia das Letras, 2017.

BEZERRA DE MENESES, UIpiano T. A fotografia como documento - Robert Capa e o miliciano abatido na Espanha: sugestões para um estudo histórico. Tempo. Rio de Janeiro, n. 14, 2002.

BINKA, Le Breton. Vidas roubadas: a escravidão moderna na Amazônia Brasileira. São Paulo: Loyola, 2002.

BUTLER, Judith. Quadros de guerra: quando a vida é passível de luto? Tradução de Sérgio Tadeu de Niemeyer Lamarão e Arnaldo Marques da Cunha. 4. ed. Rio de Janeiro: Civilização Brasileira, 2018.

CAVALCANTI, Tiago Muniz. Como o Brasil enfrenta o trabalho escravo contemporâneo. In: SAKAMOTO, Leonardo (org.). Escravidão Contemporânea. São Paulo: Contexto, 2020. 
COMISSÃO PASTORAL DA TERRA (CPT). Conflitos no campo. Brasil 2017. Goiânia: CPT, 2018.

ENTLER, Ronaldo. A fotografia e as representações do tempo. Revista Galáxia. São Paulo, n. 14, p. 29-46, dez. 2007.

FIGUEIRA, Ricardo Rezende. Pisando fora da própria sombra: a escravidão por dívida no Brasil contemporâneo. Rio de Janeiro: Civilização Brasileira, 2004.

FIGUEIRA, Ricardo Rezende. Condenados à Escravidão. In: Comissão Pastoral da Terra. Trabalho Escravo no Brasil Contemporâneo. São Paulo: Edições Loyola, 1999.

GOMES, Ângela de Castro Gomes; GUIMARAES NETO, Regina Beatriz. Trabalho escravo contemporâneo: tempo presente e usos do passado. Rio de Janeiro: FGV Editora, 2018.

GUIMARÃES NETO, Regina Beatriz; PEREIRA, Airton dos Reis. Conflitos no campo e práticas de violência: Amazônia. In: DEZEMONE, Marcus; FONTES, Edilza (org.). História oral e conflitos rurais: memórias de lutas. São Paulo: Letra e Voz, 2020.

KOSSOY, Boris. História e Fotografia. 5. ed. São Paulo: Ateliê Editorial, 2014.

KOSSOY, Boris. Realidades e Fiç̧ões na Trama Fotográfica. 5. ed. São Paulo: Ateliê Editorial, 2014.

LAET, João. Entrevista concedida a Geovanni Cabral, Marabá-PA, 26 maio 2018.

LAET, João. Entrevista concedida a Geovanni Cabral, Marabá-PA, 27 jul. 2019.

LE GOFF, Jacques. História e Memória. Tradução de Bernardo Leitão. 5. ed. Campinas: Editora da Unicamp, 2003.

LOWE, Paul. Mestres da fotografia: técnicas criativas de 100 fotógrafos. Tradução de Elson Furmankiewicz. São Paulo: Gustavo Gil, 2017.

MAUAD, Ana Maria; LOPES, Marcos Felipe de Brun. História e Fotografia. In:CARDOSO, Ciro Flamarion; VAINFAS, Ronaldo. Novos Domínios da História. Rio de Janeiro: Elsevier, 2012.

MAUAD, Ana Maria. O olhar engajado: fotografia contemporânea e as dimensões políticas da cultura visual. ArtCultura. Uberlândia, v. 10, n. 16, p. 33-50, jan./jun, 2008.

NORA, Pierre. Entre memória e história: a problemática dos lugares. Projeto História. São Paulo, v. 10, p. 7-28, jul./dez., 1993.

PORTELLI, Alessandro. História Oral como arte da escuta. Tradução de Ricardo Santiago. São Paulo: Letra e Voz, 2016.

PRADO, Andonita Antunes (org.). Olhares sobre a escravidão contemporânea: novas contribuições críticas. Cuiabá: EdUFMT, 2011.

RIPPER, João Roberto; CARVALHO, Sérgio. Retrato escravo. Organização Internacional do Trabalho (OIT). Brasília: OIT, 2010.

ROZIERS, Henri Burin des. Apaixonado por justiça: conversas com Sabine Rousseau e outros escritos. Tradução de Igor Rolemberg e Xavier Plasat. São Paulo: Elefante: Comissão Pastoral da terra, 2018.

ROZIERS, Henri Burin des. Eu sonho que cesse a violência contra os camponeses sem terra. Movimento Humanos Direitos, 09 out. 2014. Disponivel em: http://www.humanosdireitos.org/noticias/denuncias/841-FREl-HENRI--Eu-sonho-que-cesse-a-violencia-contra-os-camponeses-sem-terra.htm. Acesso em: 28 dez. 2020.

SAKAMOTO, Leonardo. Trabalho Escravo no Brasil do Século XXI. Brasília: Organização Internacional do Trabalho (OIT), 2007.

SAKAMOTO, Leonardo (org.). Escravidão Contemporânea. São Paulo: Contexto, 2020.

SILVA, Jorge Carlos Aragão. Trabalho escravo, trabalho temporário e migração. In: FIGUEIRA, Ricardo Rezende et al. Trabalho escravo contemporâneo no Brasil: contribuições críticas para análise e denúncia. Rio de Janeiro: Editora UFRJ, 2008.

SONTAG, Susan. Diante da dor dos outros. Tradução de Rubens Figueiredo. São Paulo: Companhia das Letras, 2003.

TRONCOSO, Alberto del Castillo. Las mujeres de X'Oyep. México, Conaculta, 2013.

VIEIRA, Maria Antonieta da Costa. Trabalho escravo, trabalho temporário e migração. In: FIGUEIRA, Ricardo Rezende et al. Trabalho escravo contemporâneo no Brasil: contribuições críticas para análise e denúncia. Rio de Janeiro: Editora UFRJ, 2008. 


\section{Notas}

${ }^{1}$ LAET, João. Entrevista concedida a Geovanni Cabral, Marabá-PA, 27 jul. 2019. Agradeço a João Laet por sua disponibilidade e por seu acervo fotográfico. Essas entrevistas foram interessantes como estratégia metodológica, pois à medida que visualizava as imagens descrevia a intenção e o momento do registro.

${ }^{2}$ Site da Organização Internacional do Trabalho. Ver: https://www.ilo.org/brasilia/temas/trabalho-escravo/lang--pt/index. htm. Uma página ligada às Nações Unidas que tem como foco principal promover a justiça social, de homens e mulheres, no tocante ao acesso ao trabalho com dignidade, condições liberdade e segurança. Na parte temática sobre trabalho forçado (assim que o site nomeia), há vários dados atualizados sobre o trabalho escravo no Brasil e em outras localidades do planeta.

${ }^{3}$ Site do Observatório da Erradicação do Trabalho Escravo e do Tráfico de Pessoas. Ver: https://smartlabbr.org/trabaIhoescravo/localidade/1506187?dimensao=perfilCasosTrabalhoEscravo. O SmartLab é uma plataforma de conteúdos integrados que surgiu mediante uma iniciativa do Ministério Público do Trabalho e da Organização Internacional do Trabalho, que compila dados sobre o universo do trabalho. Está dividida em cinco eixos temáticos: Trabalho Decente, Segurança e saúde no Trabalho, Erradicação do trabalho Escravo e do Tráfico de Pessoas, Prevenção e Erradicação do Trabalho Infantil e Diversidade e Igualdade de Oportunidades no Trabalho.

${ }^{4}$ LAET, João. Entrevista concedida a Geovanni Cabral. Marabá-PA, 26 maio 2018.

${ }^{5}$ LAET, João. Entrevista concedida a Geovanni Cabral. Marabá-PA, 26 maio 2018.

${ }^{6}$ LAET, João. Entrevista concedida a Geovanni Cabral. Marabá-PA, 27 jul. 2019.

${ }^{7}$ LAET, João. Entrevista concedida a Geovanni Cabral. Marabá-PA, 27 jul. 2019.

Recebido em: 29/02/2020

Aprovado em: 30/08/2020 